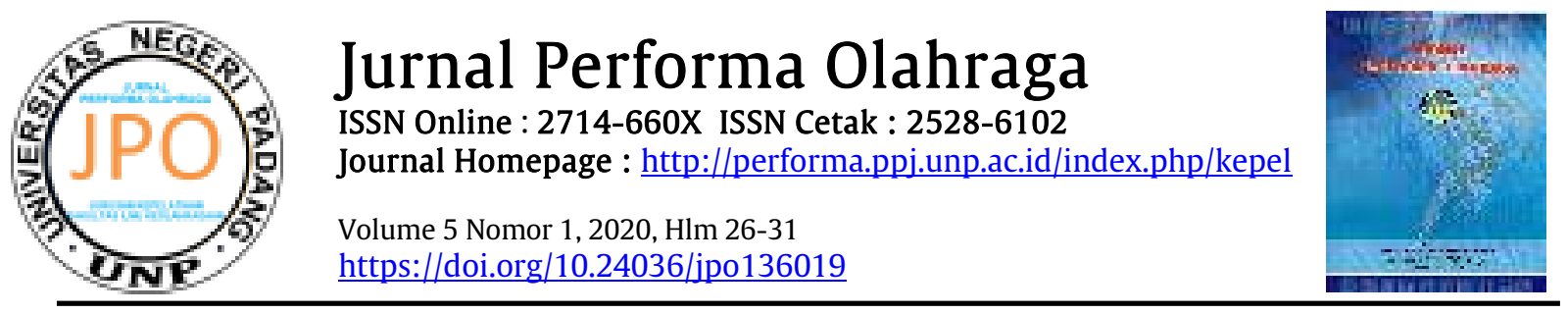

\title{
Perbedaan Latihan Passing Target dan Rangkaian Latihan Passing terhadap Kemampuan Passing Bawah Atlet Bolavoli
}

\author{
Jefri Bule ${ }^{1}$, Donie ${ }^{2}$ \\ ${ }^{1,2}$ Fakultas Ilmu Keolahragaan,Universitas Negeri Padang, Indonesia \\ E-mail: Jefribule010@gmail.com ${ }^{1}$, Donie17@fik.unp.ac.id ${ }^{2}$
}

Informasi Artikel

Diterima

Direvisi

Dipublikasikan 09-06-2020

\section{Keyword:}

Passing Exercise Method Lower Passing Ability

Athlete

Volleyball

\begin{abstract}
The problem of this research is the low passing ability under the volleyball athlete of SMAN 8 Padang. The purpose of this study was to determine the difference between the effect of target passing exercises and the series of bottom passing exercises on the under passing ability of the volleyball athletes of SMAN 8 Padang. This type of research is quasi-experimental. The study population was all volleyball athletes at SMAN 8 Padang. The sample of this study was the men's volleyball male athlete of SMAN 8 Padang totaling 16 people with technique for this study was purposive sampling. The test instrument used in this study was Repeated Volleys Test, Validity 0.80 Reliability 0.87 The analysis technique of this study used t-test. The results of this study are tcount (3.57)> ttable (1,761) passing under the target and tcount (3.69)> ttable (1.761) the series of passing exercises under both exercises there is an increase in results between the pretest and posttest. Comparison of the two forms of training to get a difference in value so as to conclude a significant difference between the form of passing target training with a series of bottom passing exercises to the under passing ability of SMAN 8 Padang volleyball athletes. meaning that the form of passing target training is more influential compared to the series of exercises.
\end{abstract}

(c) 2020 The Authors. Published by Universitas Negeri Padang.

This is an open access article under the CC BY-NC-SA license (https://creativecommons.org/licenses/by-nc-sa/4.0

\section{Penulis Korespondensi:}

Jefri Bule

Universitas Negeri Padang

Email: Jefribule010@gmail.com

\section{PENDAHULUAN}

Olaharaga merupakan suatu bentuk aktifitas fisik yang terstruktur dan terencana yang melibatkan gerakan tubuh yang di lakukan secara berulang ulang yang tujuannya untuk meningkatkan kondisi kebugaran jasmani. Selain itu juga olaharga sangat dibutuhkan setiap orang untuk mendapatkan kebugaran jasmani dengan adanya kebugaran jasmani diharapkan meningkatkan produktifitas. Disisi lain olahraga juga dapat dijadikan sabagai ajang komptesi atau pertandingan untuk berpacu dalam pencapain sebuah prestasi.

Penulis melakukan observasi pada Atlet bolavoli SMAN 8 Padang pada tanggal 25 agustus 2019. Dan kemudian penulis mendapatkan informasi prestasi bolavoli yang pernah diraih atau di menangkan, antara lain sebagai berikut : beberapa prestasi yang pernah di raih atlet bolavoli SMAN 8 yaitu, juara 2 SMANDEL CUP 2, Juara 2 SAINCOM, selain itu pada Kejurnas junior 
2017 di Tanggerang ada dua atlet SMAN 8 Padang turun mewakili SUMBAR atas nama Taufik Hanan dan Muhammad Rivan. Dari prestasi yang telah di peroleh ada beberapa hal yang membuat SMAN 8 Padang belum berhasil mendapatkan juara 1. Selanjutnya penulis melakukaan observasi kembali tepatnya di bulan 10 September 2019 untuk lebih mengetahui informasi yang didapatkan dari Coach/Pelatih SMAN 8 Padang yang membawah Tim Bolavoli SMAN 8 Padang mengikuti Event atau pertandingan POLDA CUP 2019 diadakan di Kuranji dengan observasi yang penulis lakukan Tim bolavoli SMAN 8 Padang belum bias mendapatkan hasil yang maksimal karena dalam permainan tingkat kemampuan passing pemain kurang tepat sasaran yang disebabkan menurunya kondisi fisik yang mempengaruhi teknik.

Berdasarakan hasil observasi yang peneliti lakukan dan diperkuat oleh Hasmal selaku Coach atau pelatih bolavoli SMAN 8 Padang mengatakan rendahnya kemampuan passing bawah pemain bolavoli SMAN 8 Padang ini masih rendah, hal ini dilihat pada saat pertandingan uji coba yang telah dilakukan oleh tim SMANDEL.

Menurut Hermanzoni (2019 : 294-299) “ Bolavoli merupakan olahraga permainan yang didalamnya membutuhkan kemampuan untuk mengambil keputusan dalam waktu yang singkat. Membaca arah bola serta melaksanakan strategi penyerangan membutuhkan kemampuan itelegensi yang baik dari atlet".MenurutMukholid, (2007:13) "Permainan bolavoli adalah suatu permainan yang menggunakan bola untuk dipantulkan (di-volley) di udara untuk melewati net (jaring), dengan maksud menjatuhkan bola di dalam petak daerah lapangan lawan dalam rangka mencari kemenangan".

Menurut Nuril (2010:23)" passing bawah adalah suatu teknik memainkan bola dengan sisi dalam lengan bawah".selanjutnyaMenurut Erianti berpendapat (2004:115) "passing merupakan suatu teknik dalam permainan bolavoli yang tujuannya adalah untuk mengoperkan bola ke suatu tempat atau ke teman sendiri dalam satu regu".

Berdasarakan penjelasan masalah di atas peneliti ingin memperbaiki kemampuan passing dengan memberikan dua bentuk latihan atau metode yaitu Passing Target dan Rangkaian Latihan passing merupakan salah satu bentuk latihan passing untuk meningkatkan kemampuan passing bawah atlet. Berdasarkan uraian di atas penelitian dengan judul "Perbedaan Latihan Passing Target dan Rangkaian Latihan passing terhadap kemampuan passing bawah Atlet Bolavoli SMAN 8 Padang ”.

\section{METODE}

Dalam penelitian ini penulis menggunakan metode penelitian kuantitatif Penelitian ini merupakan jenis penelitian Eksperimen semu (Quasi Eksperimen). Rancangan dalam penelitian ini adalah "The Two Group Pre-Test Desain Group". Dilakukan pada atlet bolavoli SMAN 8 Padang. Penelitian dilaksanakan tanggal 15 februari sampai 15 maret 2020 di lapangan bolavoli SMAN 8 Padang. Populasi penelitian seluruh atlet bolavoli SMAN 8 Padang. sampel penelitian iniatlet putra bolavoli SMAN 8 Padang berjumlah 16 orang. Teknik pemilihan sampel penelitianinipurposive sampling. Setelah dilakukan pre test sampel dibagi dua kelompok dengan cara ordinal matching pairing. Kelompok terdiri latihan pasing bawah target dan rangkaian latihan passing bawah yang diberikan perlakuan dengan 16 kali pertemuan. Instrumen test yang digunakan dalam penelitian ini adalah Repeated Volleys Test, Validitas 0,80 Reliabilitas 0,87(Adnan, 2005 :77-78)untuk melihat kemampuan Passing bawah pemain. Teknik analisis penelitian ini menggunakan uji-t

\section{HASIL DAN PEMBAHASAN}

\section{Hasil Penelitian}

\section{Hasil Pre-test Latihan Passing Bawah Target (Eksperimen 1)}

Berdasarkan data pre-test latihan passing bawah target dari 8 orang atlet SMAN 8 Padang sebelum diberikan treatment dengan variasi bentuk latihan passing target diperoleh nilai ratarata mean (17,5), standar deviasi (6,117),nilai varian (37,42), kemudian nilai Maximum (24), nilai minimum adalah (9).Skor kemampuan passing bawah dengan kelas interval $<8,32$ kategori 
kurang sekali dengan 0 responden (frekuensi relatif 0\%),kelas interval 8, $32-14,44$ kategori kurang 3 responden(frekuensirelatif 38\%), interval 14, 44 - 2056 kategori sedang dengan 1 responden (frekuensi relatif 13\%), kelas interval 20, 56 - 26, 68 kategori baik 4 responden dengan (frekensi relatif $50 \%$ ) dan kelas interval > 26, 68 kategori baik sekali 0 responden (frekuensi relatif $0 \%)$.

\section{Hasil Post-test Latihan Passing Bawah Target (Eksperimen 2)}

Dari tes posttest kemampuan passing bawah target setelah diberikan treatment dari 8 orang atlet bolavoli SMAN 8 Padang. Telah diberikan treatment hasil hitungan kembali untuk nilai rata-rata/mean (21,75), standar deviasi $(3,88)$, nilai varian(15,07), nilai maximum (26) dan nilai minimunya (14), Kemampuan passing bawah target dengan kelas interval $<15,93$ kategori kurang sekali dengan responden (1), dan frekuensi relatif (13\%), selanjutnya interval 15, 93 - 19, 81 kurang, responden (1), frekuensi relatif (13\%), selanjutnya interval 19, 81 - 23, 69 kategori sedang 3 responden dan frekuensi relatif (38\%) kemudiankelas interval23, 69 - 27,57kategori baikdengan 3 respondendan (frekuensi relatif $38 \%$ ) dan kelas interval $>27,57$ kategori baik sekali 0 responden dan frekuensi relatif $(0 \%)$

\section{Hasil Pre test dan Post-test Rangkaian Latihan Passing bawah Terhadap Kemampuan Passing Bawah Atlet Bolavoli SMAN 8 Padang}

\section{a. Hasil Pre test Rangkaian Latihan Passing bawah}

Dari data tes awal (pretest) rangkaian latihan passing bawah sebelum diberikan treatment dari 8 orangatletbolavoli SMAN 8 Padang diperoleh rata-rata (mean) dengan skor $(17,62)$, standar deviasi $(4,80)$, nilai varian $(23,12)$, kemudian untuk nilai maximum $(23)$ dan nilai minimum (11). Kemampuan rangkaian latihan passing bawah dengan kelas interval $<10,42$ kategori kurang sekali dengan 0 responden (frekuensi relatif 0\%),kemudiankelas interval 10,4215,22, kategori kurang 2 responden (frekuensi relatif 25\%) ,padakelas interval 15,22 - 20, 02 kategori sedang dengan 3 responden dan (frekuensi relatif $38 \%$ ) dankelas interval 20,02 - 24, 82kategori nilai baik dengan 3 respondendan ( frekuensi relatif 38\% ) selanjutnya interval $>24,82$ dengan kategori nilai baik sekali , responden 0 dan (frekuensi relatif $0 \%$ ).

\section{b. Hasil Post test Rangkaian Latihan Passing bawah}

Daripost-test kemampuan rangakain latihan passing bawah yang dilakukan setelah diberikan treatment dari 8 orang. setelahtreatment diperoleh hasil rata-rata $(21,25)$, standar deviasi $(2,43)$, nilai varian(5,92), nilai maximum yaitu (25) dan nilai minimunya (19), Kemampuan rangkaian latihan passing bawah kategori nilai sangat kurang dengan interval $<17,60$ kategori nilai kurang sekali dengan 0 respondendan (frekuensi $0 \%$ ) dan untuk kelas interval 17,60 - 20,03 kategori nilai kurang dengan 4 responden dan (frekuensi relatif $50 \%$ ) selanjutnya kelas interval 20,03-22,46 kategori nilai sedang dengan 1 responden dan (frekuensi relatif $13 \%$ ) kemudian kelas interval 22,46-24,89 kategori nilai baik dengan 2 responden untuk (frekuensi relative 25\%) dankela interval $>24,89$ dengankategorinilaibaiksekalidengan 1 responden.Maka dapat disimpulkan bahwasanya bentuk rangkaian latihan passing bawah (RLPB) setelahdiberikanperlakuanmendapatkanpeningkatanhasi yang signifikan.

\section{PEMBAHASAN}

\section{Terdapat Pengaruh Latihan Passing Bawah Target Terhadap Kemampuan Passing Bawah Atlet Bolavoli SMA N 8 Padang}

Berdasarkan pre test dan post test kemampuan passing bawah dan analisis uji hipotesis diperoleh harga $\left(t_{\text {hitung }} 3,57\right.$. $)>t_{\text {tabel }}(1.761)$ pada taraf signifikansi $\alpha=0,05$ dapat disimpulkan bahwa $\mathrm{H}_{\mathrm{o}}$ ditolak dan $\mathrm{H}_{\mathrm{a}}$ diterima. Dengan demikianmenunjukan bahwa adanya pengaruh signifikan bentuk latihan passing bawah target terhadap kemampuan passing bawah atlet bolavoli SMA N 8 Padang. Dengan hasil uji t diperoleh mean pre-test 17, 5 dan post test 21,75 dan nilai $t_{\text {hitung }} 3,57$.

Passing bawah target merupakan salah satu bentuk latihan mengarakan bola dengan passing bawah menggunakan kedua lengan dengan bantuan target sasaran untuk melatih 
koordinasi dan gerakan terotomatisasi. Dalam penelitian ini yang dimaksud dengan passing bawah target adalah teknik passing bawah dalam permainan bolavoli, passing bawah ini salah satu elemen yang terpentingdalambermaianbolavoliuntukmelakukanpassing perlunyagerakan yang automatisasi antara gerakan kaki dan perkenaaan, selanjutnya ada faktor yang mempengaruhi untuk peningkatan passing bawah diantaranya dari internal dan eksternal. Faktor dari dalam diri yaitu motivasijugasangat mempengaruhi atlet dalam berlatih Motivasi sebagai sumber penggerak dan pendorong yang bersifat dinamik, dapat di pengaruhi, merupakan cerminan sikap dan mendorong suatu tindakan terarah pada tujuan untuk mendapatkan kepuasan atau menghindari hal- hal yang tidak menyenangkan baik yang di sadari maupun yang tidak di sadari dan berhubungan dengan aspek kognitif, motorik dan afektif.

\section{Adanya Pengaruh Latihan Rangkaian Latihan Passing Bawah Terhadap Kemampuan Passing Bawah Atlet Bolavoli SMA N 8 Padang}

Berdasarkan pre test dan post test kemampuan passing bawah dan analisis uji hipotesis diperoleh harga $\left(t_{\text {hitung }} 3,69\right.$. $)>t_{\text {tabel }}$ (1.761)pada taraf signifikansi $\alpha=0,05$ dapat disimpulkan bahwa Ho ditolak dan Ha diterima. Dengan demikianmenunjukan bahwa adanya pengaruh signifikan bentuk rangkaian latihan passing bawah terhadap kemampuan passing bawah atlet bolavoli SMA N 8 Padang. dengan hasil uji t diperoleh mean pre test 17, 62 dan post test 21, 25 dan nilai $t_{\text {hitung }} 3,69$. Metode rangkaian latihan passing bawah ini merupakan salah satu bentuk latihan yang memiliki tingkat variasi dalam latihan sehinggah timbulnya tingkat latihan dari tingkat yang sederhana - komplek, yang mudah - sukar,selain itu juga bentuk latihan ini lebih efektif karena dalam pelaksanaan latihan ini memiliki bermacam macam gerakan yang bertujuan melatih kemampuan passing bawah dengan gerakan gerakan yang terencana.

\section{Adanya Perbedaan Latihan passing bawah target dan Rangkaian Latihan Passing Bawah Terhadapp Kemampuan Passing Bawah Atlet Bolavoli SMA N 8 Padang}

Berdasarkan pre test dan post test kemampuan passing bawah bolavoli, menunjukan bahwa terdpat perbedaan yang signifikan antara bentuk latihan passing target dengan rangkaian latihan passing bawah terhadap kemampuan passing bawah atlet bolavoli SMA N 8 Padang. Diperoleh mean post test bentuk latihan passing bawah target sebesar 21, 75 dan standar deviasi 3 , 88 dengan nilai $t_{\text {hitung }} 3$, 57. Sedangkan diperoleh kelompok rangkaian latihan passing bawah yaitu 21, 25 dan standar deviasai 2, 43 dengan nilai $t_{\text {hitung }} 3$, 69. Berdasarkan uji hipotesis dari hasil penelitian bentuk latihan passing bawah target memiliki tingkat pengaruh yang signfikan dibandingkan dengan rangkaian latihan passing atlet bolavoli SMA N 8 Padang, mendapatkan perbedaan nilai post test mean 21, 75 untuk bentuk latihan passing bawah target dan post test mean 21,25 bentuk rangkaian latihan passing.

\section{KESIMPULAN}

Berdasarkan hasil penelitian yang telah diperoleh dengan analisis data dan pengujian hipotesis, dapat disimpulkan Ada pengaruh yang signifikan bentuk latihan passing target terhadap kemampuan passing bawah Atlet Bolavoli SMAN 8 Padang, dengan mean pre test 17,5

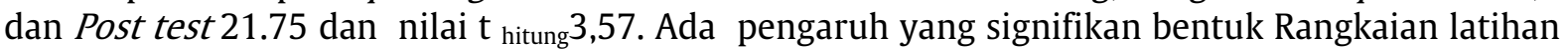
passing bawah terhadap kemampuan passing bawah Atlet Bolavoli SMAN 8 Padang, dengan mean pre test 17,625 dan Post Test 21.25 dan nilai $\mathrm{t}$ hitung3,69.Terdapat perbedaan yang signifikan antara bentuk latihan passing target dengan Rangkaian latihan passing bawah yaitu bentuk latihan dengan uji hipotesis mean bentuk latihan passing target 21, 75 dan mean rangkaian latihan passing 21, 25danhasilmenunjukanbentuklatihanpassingtargetlebihefektifdigunakan.Denganhasilpenelitiani nidiharapandapatmenjadipedomanuntukmelakukanpenelitian selanjutnya.

\section{DAFTAR PUSTAKA}

Ahmadi , Nuril . 2007. Panduan Olahraga Bola Voli. Surakarta: Era Pustaka Utama Akbar, R. (2019). Pengaruh Metode Latihan Permainan Target Terhadap Keterampilan Passing Atas. Jurnal Patriot, 2(3), 532-543. 
Akhbar, T.M. (2013). Pengaruh Metode Rangkaian Bermain, Latihan dan Agresifitas Instrumental Terhadap Keterampilan Bermain Sepakbola SSB Putra Wijaya Kota Padang.). Padang: Universitas Negri Padang.

Agus Mukholid. 2007. Pendidikan Jasmani Olahraga dan Kesehatan. Jakarta timur : Yudistira.

Arikunto, Suharsini . 2010. Prosedur Penelitian: Suatu Pendekatan Praktek. Jakarta: Rineka Cipta.

Astuti,.B \& fatiamaningrum ,A.S (2017). Pengembangan panduan permainanan untuk mengomptimlakan perkembangan sosial emosional anak usia dini.jurnal pendidikan anak $1(5)$

Astuti Yuni (2017). Pengaruh Metode Drill dan Metode Bermain Terhadap Keterampilan Bermain Bolavoli Mini (Studi Eksperimen Pada Siswa SD Negeri 14 Kampung Jambak Kecamatan Koto Tangah Kota Padang). Jurnal Al Ibtida. Vol 4 No. 1.

Aziz, I., \& Donie, D. (2017). Profil Kondisi Fisik Mahasiswa Fakultas IImu Keolahragaan Universitas Negeri Padang. Jurnal Performa Olahraga, 2(02), 132-142.

Bachtiar. 2007. Permainan besar ii: bola voli dan bola tangan. Jakarta: Universitas Terbuka.

Blume, R. . 2004. Teknik Dasar Bola Voli. Penerbit Usaha Nasional: Surabaya

Bompa. 1999. Tudor O. Theory and Methodology of Training.Dubuque, Lowa:Kendal/Hunt Publishing Company.

Daya, W. J., Chan, F., \& Muzaffar, A. (2017). Penerapan Modifikasi Permainan Target UntukMeningkatkan Kreatifitas Mahasiswa Terhadap Pembelajaran Bola Voli Fik Universitas Jambi. Multilateral Jurnal Pendidikan Jasmani dan Olahraga, 16(2).

Edy Sih Mitranto. (2010). Pendidikan Jasmani Olahraga dan Kesehatan Penjas Orkes: Kelas VI. Jakarta: Pusat Perbukuan, Kementerian Pendidikan Nasional

Erianti.2014. Bola Voli (Bahan Ajar). Padang: FIK UNP

Faruq, M.M. .2009. Meningkatkan kebugaran jasmani melalui permainan dan olahraga bola voli. Jakarta: PT Gramedia Widiasarana Indonesia.

Fardi, Adnan. 2010. Silabus dan Hand-out Statistik. Padang:FIK UNP

Faozi, F., Jaelani, J., \& Fikri, A. (2019). Pengaruh Latihan Permainan Target Terhadap Passing Atas Pada Siswa Putra Ekstrakurikuler Bola Voli Di Sekolah Menengah Kejuruan Doa Bangsa Palabuhanratu. Jurnal Olympia, 1(2), 1-7.

Harsono. 2015. Kepelatihan olahraga. (teori dan metodologi). Bandung: Remaja Rosdakarya

Haq, A., \& Hermanzoni, H. (2019). Analisis Tingkat Kemampuan Teknik Dasar Atlet Bolavoli Putra Klub Ikatan Pemuda Tanjung Betung Kabupaten Pasaman. Jurnal JPDO, 2(1), 294-299.

Hendriani, U. O., \&Donie, D. (2019). Kontribusi Daya Ledak Otot Lengan, Otot tungkai dan Koordinasi Mata Tangan terhadap Ketepatan Smash Atlet Bolavoli. Jurnal JPDO, 2(1), 119-125.

Hermanzoni, dkk. 1995. Pengembangan Tes Keterampilan Motorik Bola Voli Dalam Perkuliahan Tingkat Dasar Mahasiswa FPOK IKIP Padang. Padang: IKIP

Hernawan, A.H. (2013). Pengembangan kurikulum dan pembelajaran. Tangerang Selatan: Universitas Terbuka

Imam, Sadikun dkk. 1992. Permainan Bola Besar. Jakarta : Depdikbu

Hendri,Irawadi. 2019. Kondisi Fisik dan Pengukurannya.Padang : UNP Press.

Hendri,Irawadi. 2013. Kondisi Fisik dan pengukuran. Padang: FIK UNP

Junaidi, A., \& Mushofi, Y. 2019 . Perbedaan Pengaruh Latihan Berpasangan Sentuhan Bola Satu Kali dan Berpasangan Sentuhan Bola Dua Kali Terhadap Kemampuan Passing Atas Bola Voli. Jendela Olahraga, 4(1).

Langford, G. A, et al. (2004). Effects of single- leg resistance training on measurement of jumping performance in NCCAA division II Women Volleyball Players. Valdosta State University, Georgia (USA).

Ma'mum A (2001).pemndekata keterampilan taktis dalam pembelajaran bolavoli . Jakarta : direktur Jendaral olahraga

Muhajir. 2006. Pendidikan Jasmani Olahraga dan Kesehatan. Jakarta: Erlangga.

Oktitaindah.2012,faktor penentu latihan teknik.www.blogspot.com. diakses 15 januari 2020

Permana, H., \& Suharjana, S. (2013). Pengaruh Sirkuit Training Awal Akhir Latihan Teknik Terhadap Kardiorespirasi, Power, Smash, Passing Bawah Atlet Bola Voli. Jurnal Keolahragaan, 1(1), 49-62. 
Putra, R. E. (2019). Pengaruh Metode Rangkaian Latihan Terhadap Kemampuan Passing Pemain Sepakbola. Jurnal JPDO, 2(1), 254-259.

Qadavi, M., \& Eka_Putra, R. (2019,). Pengaruh Metode Rangkaian Latihan Terhadap Kemampuan Passing Pemain Sepakbola Ssb Putra Wijaya Padang. In International Conference on Educational Technologi 